\title{
PHARMACEUTICAL COMPOSITIONS BASED ON INFUSIONS/ EXTRACTS OF BLACK WALNUTS/WALNUT IN INFECTIOUS PATHOLOGY AND WOUND HEALING COMPLICATIONS
}

\author{
ЛІКАРСЬКІ КОМПОЗИЦІЇ НА ОСНОВІ НАСТОЯНОК/ \\ ЕКСТРАКТІВ ГОРІХІВ ЧОРНОГО/ВОЛОСЬКОГО У \\ ІНФЕКЦІЙНІЙ ПАТОЛОГІЇ РАН ТА РАНОВИХ УСКЛАДНЕНЬ
}

\author{
Valeriy Minukhin ${ }^{1}$ \\ Viktor Kazmirchuk ${ }^{2}$ \\ Inna Torianyk ${ }^{3}$
}

DOI: https://doi.org/10.30525/978-9934-588-15-0-68

\begin{abstract}
The significance of the problem of surgical infections of soft tissues is determined by the facts of primary treatment for special medical care, which in the overall structure make up $70 \%$. Statistics of nosocomial infectious pathology today exceeds almost $95 \%$ of cases in some countries (postoperative complications). The most common complication of the postoperative period in patients is suppuration of the wound. The most common complication of the postoperative period in patients is suppuration of wounds, which are from 3 to $30 \%$. The importance of this pathology can be evidenced by the fact that the mortality rate in the case of such diseases (including necrotic fasciitis reaches 50\%). In Ukraine, monitoring of this pathology is being carried out, which has contributed to the annual registration of more than 12 million cases of slaughter, wounds, fractures of the upper and lower extremities, with subsequent occurrence of purulent processes complicated by mixed microflora and fungi. The rational treatment of wounds is one of the most acute and complex problems, which will be dealt with by more than
\end{abstract}

\footnotetext{
${ }^{1}$ DM, Professor, Head of State Institution «I. Mechnikov Institute of Microbiology and Immunology National Academy of Medical Sciences of Ukraine», Ukraine

${ }^{2} \mathrm{PhD}$, Head of Laboratory Antimicrobial, Laboratory of Antimicrobial Agent's, State Institution «I. Mechnikov Institute of Microbiology and Immunology

National Academy of Medical Sciences of Ukraine», Ukraine

${ }^{3} \mathrm{PhD}$, Leader Research Scientists at Laboratory of Viral Infection,

State Institution «I. Mechnikov Institute of Microbiology and Immunology

National Academy of Medical Sciences of Ukraine», Ukraine

(C) Valeriy Minukhin, Viktor Kazmirchuk, Inna Torianyk
} 
one generation of doctors. The ever-changing concept of a wound process, the dynamic development of surgery and antimicrobial chemotherapy, is constantly raising new demands on algorithms for treating wound infection. Among the latter, the most affordable, effective, appropriate are herbal remedies. Researchers' interest in the use of phyto raw materials (Chinese poplar extracts, walnut and black walnut leaves, broccoli cabbage, oak bark, etc.) is largely caused by antimicrobial, anti-inflammatory and reparative properties (Chinese poplar extracts, walnut and black bark hazelnut leaves, oak, etc.) of the latter. Last but not least, the chemical composition of fruits and leaves of walnut and black walnut, represented by phenolic compounds (naphthoquinones, flavonoids, phenolcarboxylic acids, tannins), proteins, vitamins, fatty oils, carbohydrates, has a positive effect on the treatment. macro and micronutrients. Black and walnuts have been investigated in Ukraine since 1809. These plants have unique pharmacological properties. According to the content of biologically active substances, yuglon and flavonoids, they exceed their other singing relatives 4-5 times. Fertilized immature fruits contain more vitamin $\mathrm{C}$ than black currant. By the way, the quantitative composition of plants includes vitamins A, B, PP, essential oils, sugars, quinones, tannins, eel and branch acids, naphthaquinone, quercetin, catechin, hyperazide, campferol and others. The latitude of therapeutic action, immunocorrection and antioxidant properties, black walnuts and walnuts have no analogues in the plant world. They remain the subject of multilateral research, including in pharmacy, as a potential source of petroquinonecontaining medicinal plant material. Therefore, the relevance of the use of medicinal compositions based on tinctures / extracts of black / walnuts in infectious pathology of wounds and wound complications is not in doubt. Experimental, microbiological, cultural, physical and physico-chemical, pharmacological and statistical methods of investigation were used as a methodological basis. As a result of the conducted experiments, the effective ratio of active substances by wound healing effect on the experimental model of the wound process, antimicrobial activity (indicators of $\mathrm{MIC}, \mathrm{MBcK}$ and IFC), the developed compositions, the optimal composition of a relatively broad spectrum of strains of microorganisms, inflammatory organs, were determined actions. Alcoholic tinctures / black walnut extracts, ointment compositions in the form of ointments with different concentrations the above substances meet the standard requirements. 


\section{1. Вступ}

Значимість проблеми хірургічних інфекцій м'яких тканин визначається фактами первинного звернення за спеціальною медичною допомогою, які у загальній структурі становлять 70\%. Статистика внутрішньолікарняної інфекційної патології перевищує на сьогодні по деяким країнам майже 95\% випадків (післяопераційні ускладнення). Найчастішим із ускладнень післяопераційного періоду у хворих є нагноєння рани, що становлять від 3 до 30\%. Про важливість цієї патології у світі може свідчити і той факт, що летальність у разі таких захворювань (у тому числі, некротичний фасціїт сягає 50\%). В Україні проводиться моніторинг за вказаною патологією, який сприяв щорічній реєстрації понад 12 млн. випадків забоїв, ран, переломів кісток верхніх і нижніх кінцівок з подальшим виникненням гнійних процесів, ускладнених змішаною мікрофлорою та грибами [9, p. 2-4; 10, р. 3-6; 11, p. 2-14; 12, p. 1-4].

Раціональне лікування ран - одна 3 найбільш гострих і складних проблем, ефективним рішенням якого буде займатися ще не одне покоління лікарів. Уявлення про рановий процес, що весь час змінюється, динамічний розвиток хірургії, антимікробної фітотерапії постійно висувають нові вимоги до алгоритмів лікування ранової інфекції та її ідентифікації [3, p. 28-34; 7, p. 173-180; 8, p. 3-4]. Серед останніх найбільш доступними, дієвими, доцільними вважають рослинні препарати. Інтерес дослідників щодо застосування фітосировини (екстракти тополі китайської, листя горіхів волоського та чорного, трави капусти броколі, кори дуба, тощо [1, р. 180-184; 5, р. 58; 14, р. 511-521; 15, p. 325-333]) великою мірою спричинений протимікробними, протизапальними i репаративними властивостями (екстракти тополі китайської, листя горіхів волоського та чорного, трави капусти броколі, кори дуба, препаратів апітерапії, тощо) останньої [2, р. 15-22; 4, p. 101; 6, p. 37]. Не останне місце у плані досягнення позитивних ефектів у лікуванні має хімічний склад плодів і листя горіха волоського і горіха чорного, що представлений фенольними сполуками (нафтохінони, флавоноїди, фенолкарбонові кислоти, дубильні речовини), білками, вітамінами, жирним маслом, вуглеводами, органічними кислотами, макро- і мікроелементами. На території України горіхи чорний та волоський почали досліджувати з 1809 року. Зазначені рослини відрізняються унікальними фармакологічними властивостями. 
За вмістом біологічно активних речовин, юглону і флавоноїдів, вони перевершують інших свої спів родичів у 4-5 разів. Оплодені незрілих плодів містять вітаміну С більше, ніж чорна смородина. До речі кількісний склад рослин долучає вітаміни А, В, РР, ефірні масла, цукри, хінони, дубильні речовини, елагову і галусову кислоти, нафтахінон, кверцетин, катехін, гіперазід, кемпферол та ін. За широтою терапевтичної дії, імунокоректорними і антиоксидантними властивостями, горіхам чорному та волоському немає аналогів в рослинному світі $[16$, p. 4503-4511; 17, p. 15-18]. Вони й досі залишаються об'єктами багатосторонніх досліджень, в тому числі в фармації, в якості потенційного джерела лікарської рослинної сировини, що містить нафтохінони. Отже, актуальність застосування лікарських композицій на основі настоянок/екстрактів горіхів чорного/ волоського у інфекційній патології ран та ранових ускладнень не викликає сумніву. У якості методичного підгрунття застосовували експериментальні, мікробіологічних, культуральні, фізичні і фізико-хімічні, фармакологічні, статистичні методи дослідження. У результаті проведених дослідів було визначене ефективне співвідношення діючих речовин за ранозагоювальною дією на експериментальній моделі ранового процесу, протимікробну активність (показники МІК, МБцК і МФК), розроблених композицій, оптимальний склад відносно поширеного спектру штамів мікроорганізмів, що притаманні рановому процесу, його протизапальній, ранозагоювальній дії. Спиртові настоянки/екстракти горіхів чорного і волоського, композицій у формі мазі з різною концентрацією вищезазначених речовин відповідають стандартним вимогам.

\section{2. Вивчення протимікробної дії експериментальних зразків екстрактів (настоянок) горіхів чорного і волоського}

Вивчення протимікробної активності дослідних зразків настоянки горіха волоського спиртової, екстракту горіха волоського вуглекислотного та настоянки горіха чорного спиртової проводили за стандартним методом послідовних серійних розведень у поживному середовищі у відношенні до тест - штамів мікроорганізмів $S$. aureus ATCC 25923, $S$. aureus ATCC 6538-P, S. pneumoniae ATCC 49619, B. cereus ATCC 10702, E. coli ATCC 25922, P. aeruginosa ATCC 27853, P. vulgaris ATCC 4636, C. albicans АТCC 885-653. Мікробне навантаження становило 
0,5 за стандартом McFarland. За цим керувались досвідом попередніх розробників лікарських речовин із застосуванням аналогічної рослинної речовини, ретельно відпрацьовуючи кожен із послідовних технічних етапів [1, p. 180-184; 4, p. 101; 13, p. 11-129].

Початкова концентрація спиртових настоянок горіхів чорного та волоського складала 1000 мкг/мл , а початкова концентрація екстракту горіха волоського вуглекислотного - 800 мкг/мл. У якості контролю використовували референтний препарат Календули настоянку $1 \%$. Результати досліджень наведені в таблицях 1-2.Результати контролю розчинів спирту етилового, об'ємна частка якого 96\%, у таблицях не наведені за відсутністю прояву його впливу на протимікробну активність. Результати досліджень наведені в таблиці 1.В результаті проведеного експерименту (табл. 2) встановлено високу протимікробну активність спиртової настоянки горіха чорного із МІК у відношенні до: $S$. aureus ATCC 25923, S. aureus ATCC 6538-P, P. aeruginosa ATCC 27853 і $C$. albicans ATCC 885-653 - 62,5 мкг/мл. МІК щодо E. coli ATCC 25922, B. cereus АТCC 10702 і S. pneumoniae АТCC 49619 дослідного зразка становила 125,0 мкг/мл, відповідно, у відношенні до P. vulgaris ATCC 4636 протимікробна дія спиртової настоянки горіха чорного була дещо менша і складала 250,0 мкг/мл.

Результати аналізу протимікробної активності дослідного зразка за $\mathrm{MБ}_{\text {ц }}$ К відносно практично усіх досліджуваних тест-штамів показали аналогічну тенденцію прояву протимікробної дії даного зразка, що визначені за МІК. Відносно до B. cereus АТCC 10702 і C. albicans АTCC 885-653 протимікробна активність спиртової настоянки горіха чорного за МБ К і МФК у порівнянні з МІК була у 2 рази нижча і складала 250,0 мкг/мл та 125,0 мкг/мл, відповідно. За результатами порівняння протимікробної активності за МІК, МБ К і МФК експериментального зразка з референтним препаратом встановлено, що у відношенні практично до усіх досліджуваних тест-штамів, крім B. cereus ATCC 10702, протимікробна дія спиртової настоянки горіха чорного значно перевищувала показники референтного препарату. Аналіз результатів протимікробної активності спиртової настоянки горіха волоського за МІК (табл. 2.2) показав, що відносно S. aureus ATCC 25923, S. aureus ATCC 6538-P, E. coli ATCC 25922 і P. aeruginosa ATCC 27853 протимікробна дія даного зразка складала 125,0 мкг/мл. Відносно решти тест-штамів 
Valeriy Minukhin, Viktor Kazmirchuk, Inna Torianyk

Таблиця 1

Протимікробна активність експериментальних зразків спиртової настоянки горіха чорного

\begin{tabular}{|c|c|c|c|c|c|}
\hline \multirow{3}{*}{$\begin{array}{l}\text { № } \\
3 / \text { II }\end{array}$} & \multirow{3}{*}{$\begin{array}{c}\text { Тест-штам } \\
\text { мікроорганізму }\end{array}$} & \multicolumn{4}{|c|}{ Протимікробна активність (мгк/мл) } \\
\hline & & \multicolumn{2}{|c|}{$\begin{array}{l}\text { Настоянка горіха } \\
\text { чорного спиртова }\end{array}$} & \multicolumn{2}{|c|}{$\begin{array}{c}\text { Календули } \\
\text { настоянка }\end{array}$} \\
\hline & & МIК & $\begin{array}{l}\text { МБцК/ } \\
\text { МФК }\end{array}$ & МІК & $\begin{array}{c}\text { МБцК/ } \\
\text { МФК }\end{array}$ \\
\hline 1 & 2 & 3 & 4 & 5 & 6 \\
\hline 1 & S. aureus ATCC 25923 & $62,5^{1)}$ & $62,5^{1)}$ & 125,0 & 250,0 \\
\hline 2 & S. aureus ATCC 6538-P & $62,5^{1)}$ & $62,5^{1)}$ & 125,0 & 250,0 \\
\hline 3 & E. coli ATCC 25922 & $125,0^{1)}$ & $125,0^{1)}$ & 250,0 & 250,0 \\
\hline 4 & P. aeruginosa ATCC 27853 & $62,5^{1)}$ & $125,0^{1)}$ & 250,0 & 250,0 \\
\hline 5 & B. cereus ATCC 10702 & 125,0 & $250,0^{1)}$ & 125,0 & 125,0 \\
\hline 6 & S. pneumoniae ATCC 49619 & $125,0^{1)}$ & $125,0^{1)}$ & 250,0 & 250,0 \\
\hline 7 & P. vulgaris ATCC 4636 & 250,0 & 250,0 & 250,0 & 250,0 \\
\hline 8 & C. albicans ATCC $885-653$ & $62,5^{1)}$ & $125,0^{1)}$ & 250,0 & 250,0 \\
\hline
\end{tabular}

${ }^{1)}-\mathrm{U}_{\mathrm{f}} \leq \mathrm{U}_{\mathrm{st}}$ при $\mathrm{p}=0,05$ у порівнянні з показником референтного препарату.

МІК дослідного зразка дорівнювалась 250,0 мкг/мл. Протимікробна активність зразка екстракту горіха волоського вуглекислотного за МІК була високою відносно E. coli ATCC 25922 і P. aeruginosa ATCC 27853. У відношенні тест-штамів $S$. aureus ATCC 25923, $S$. aureus ATCC 6538-P, B. cereus ATCC 10702, P. vulgaris ATCC 4636 i C. lbicans ATCC 885-653 протимікробна активність дослідного зразка за МІК складала 100,0 мкг/мл. Протимікробна активність спиртової настоянки горіха волоського за МБ К відносно практично усіх досліджуваних тест-штамів, крім E. coli ATCC 25922, і за МФК щодо C. albicans ATCC 885-653, була у 2 рази нижча, ніж за МІК і дорівнювалась 250,0 мкг/мл. Показники протимікробної активності екстракту горіха волоського вуглекислотного за МБ К відносно $S$. aureus АТCC 25923, S. aureus АTCC 6538-P, E. coli АТCC 25922, S. pneumoniae АТCC 49619 і за МФК відносно C. albicans ATCC 885-653 були на одному рівні з показниками за МІК. У відношенні тест-штамів $P$. aeruginosa ATCC 27853, B. cereus ATCC 10702 і P. vulgaris АТCC 4636 протимікробна активність експериментального зразка за МБ К складала 100,0 мкг/мл, 100,0 мкг/ мл і 200,0 мкг/мл, відповідно. 
Таблиця 2

Протимікробна активність експериментальних зразків

настоянки та екстракту горіха волоського

\begin{tabular}{|c|c|c|c|c|c|c|c|}
\hline \multirow{3}{*}{$\begin{array}{c}\text { № } \\
\text { 3/II }\end{array}$} & \multirow{3}{*}{$\begin{array}{c}\text { Тест-штам } \\
\text { мікроорганізму }\end{array}$} & \multicolumn{6}{|c|}{ Протимікробна активність (мкг/мл) } \\
\hline & & \multicolumn{2}{|c|}{$\begin{array}{l}\text { Настоянка } \\
\text { спиртова }\end{array}$} & \multicolumn{2}{|c|}{$\begin{array}{c}\text { Екстракт } \\
\text { вуглекислотний }\end{array}$} & \multicolumn{2}{|c|}{$\begin{array}{c}\text { Календули } \\
\text { настоянка }\end{array}$} \\
\hline & & МIK & $\begin{array}{c}\text { МБцК/ } \\
\text { МФК }\end{array}$ & МIK & $\begin{array}{l}\text { МБцК/ } \\
\text { МФК }\end{array}$ & МIK & $\begin{array}{c}\text { МБцК/ } \\
\text { МФК }\end{array}$ \\
\hline 1 & 2 & 3 & 4 & 5 & 6 & 7 & 8 \\
\hline 1 & \begin{tabular}{|l} 
S. aureus \\
ATCC 25923
\end{tabular} & 125,0 & 250,0 & $100,0^{1)}$ & $100,0^{1)}$ & 125,0 & 250,0 \\
\hline 2 & $\begin{array}{l}\text { S. aureus } \\
\text { ATCC 6538-P }\end{array}$ & 125,0 & 250,0 & $100,0^{1)}$ & $100,0^{1)}$ & 125,0 & 250,0 \\
\hline 3 & \begin{tabular}{|l} 
E. coli \\
ATCC 25922 \\
\end{tabular} & 125,0 & 125,0 & 50,0 & 50,0 & 250,0 & 250,0 \\
\hline 4 & $\begin{array}{l}\text { P. aeruginosa } \\
\text { ATCC } 27853\end{array}$ & $125,01)$ & 250,0 & $50,0^{1)}$ & $100,0^{1)}$ & 250,0 & 250,0 \\
\hline 5 & $\begin{array}{l}\text { B. cereus } \\
\text { ATCC } 10702\end{array}$ & $250,01)$ & $250,01)$ & $100,0^{1)}$ & $200,0^{1)}$ & 125,0 & 125,0 \\
\hline 6 & $\begin{array}{l}\text { S. pneumoniae } \\
\text { ATCC } 49619\end{array}$ & 250,0 & 250,0 & $200,0^{1)}$ & $200,0^{1)}$ & 250,0 & 250,0 \\
\hline 7 & $\begin{array}{l}\text { P. vulgaris } \\
\text { ATCC } 4636\end{array}$ & 250,0 & 250,0 & $100,0^{1)}$ & $200,0^{1)}$ & 250,0 & 250,0 \\
\hline 8 & $\begin{array}{l}\text { C. albicans } \\
\text { ATCC } 885-653\end{array}$ & 250,0 & 250,0 & $100,0^{1)}$ & $100,0^{1)}$ & 250,0 & 250,0 \\
\hline
\end{tabular}

1) $-\mathrm{U}_{\mathrm{f}} \leq \mathrm{U}_{\mathrm{st}}$ при $\mathrm{p}=0,05$ у порівнянні 3 показником референтного препарату.

Порівняння показників протимікробної активності за МІК, МБ К К МФК експериментальних зразків з референтним препаратом показало ідентичні значення протимікробної активності спиртової настоянки горіха волоського з препаратом порівняння відносно $S$. aureus ATCC 25923, S. aureus ATCC 6538-P, S. pneumoniae ATCC 49619, P. vulgaris ATCC 4636 і $C$. albicans ATCC 885-653 та дещо вищу активність відносно B. cereus ATCC 10702. Екстракт горіха волоського вуглекислотний за визначеними показниками протимікробної активності (МІК, МБ $\mathrm{K}$, МФК) проявив більшу активність відносно усіх досліджуваних тест-штамів у порівнянні як з референтним препаратом, так і з спиртовою настоянкою горіха волоського. 
За результатами проведених досліджень доведено високу протимікробну активність спиртової настоянки горіха чорного відносно $S$. aureus ATCC 25923, S. aureus ATCC 6538-P, P. aeruginosa ATCC 27853 i C. albicans ATCC 885-653 та екстракту горіха волоського вуглекислотного відносно P. aeruginosa АТCC 27853 і B. cereus АТCC 10702. Відносно решти досліджуваних тест-штамів усі експериментальні зразки проявили дещо нижчу активність.

\section{3. Створення лікарських композицій на основі настоянок/екстрактів горіхів чорного}

та волоського вуглекислотних 3 допоміжними речовинами

Розробку складу лікарських протимікробних композицій з спиртовими настоянками горіха чорного або горіха волоського або з екстрактом горіха волоського вуглекислотного, мірамістином і лідокаїну гідрохлоридом проводили за стандартною технологічною схемою. В якості допоміжних речовин у експериментальних зразках використовували ПЕО 1500, ПЕО 400, ДМСО, полісорбат 80.

Зразки якісного і кількісного складу експериментальних композицій з спиртовою настоянкою горіха чорного різного вмісту у комбінації 3 мірамістином і лідокаїну гідрохлоридом наведені у таблиці 3.

Таблиця 3

\section{Склад експериментальних композицій}

з спиртовою настоянкою горіха чорного

\begin{tabular}{|l|c|c|c|c|c|c|c|c|c|}
\hline \multirow{2}{*}{$\begin{array}{c}\text { Найменування } \\
\text { інгредіснту }\end{array}$} & $\mathbf{1}$ & $\mathbf{2}$ & $\mathbf{3}$ & $\mathbf{4}$ & $\mathbf{5}$ & $\mathbf{6}$ & $\mathbf{7}$ & $\mathbf{8}$ & $\mathbf{9}$ \\
\cline { 2 - 11 } \\
\hline $\begin{array}{l}\text { Настоянка горіха } \\
\text { чорного спиртова }\end{array}$ & 5,0 & 5,0 & 5,0 & 5,0 & 10,0 & 10,0 & 10,0 & 10,0 & - \\
\hline Мірамістин & - & - & - & 0,5 & - & - & - & 0,5 & 0,5 \\
\hline $\begin{array}{l}\text { Лідокаїну } \\
\text { гідрохлорид }\end{array}$ & 2,0 & 3,0 & 3,0 & 3,0 & - & - & 5,0 & 5,0 & - \\
\hline ДМСО & 3,0 & 3,0 & 3,0 & 3,0 & 3,0 & 3,0 & 3,0 & 3,0 & 3,0 \\
\hline Полісорбат 80 & - & - & 3,0 & - & - & 3,0 & 3,0 & 3,0 & 3,0 \\
\hline ПЕО 1500 & 22,0 & 22,0 & 23,0 & 22,0 & 23,0 & 23,0 & 19,0 & 19,0 & 22,0 \\
\hline ПЕО 400 & 68,0 & 69,0 & 63,0 & 66,5 & 64,0 & 61,0 & 60,0 & 59,5 & 71,5 \\
\hline
\end{tabular}


Виготовлені зразки комбінованої мазі на основі спиртової настоянки горіха чорного відповідають вимогам ДФУ 2. Зразки якісного та кількісного складу експериментальних композицій з спиртовою настоянкою горіха волоського різного вмісту у комбінації з мірамістином і лідокаїну гідрохлоридом наведені у таблиці 4.

Таблиця 4

\section{Склад експериментальних композицій}

3 спиртовою настоянкою горіха волоського

\begin{tabular}{|l|c|c|c|c|}
\hline \multirow{2}{*}{\multicolumn{1}{|c|}{ Найменування інгредіснту }} & \multicolumn{4}{|c|}{ № складу на 100 г, г } \\
\cline { 2 - 5 } & $\mathbf{1}$ & $\mathbf{2}$ & $\mathbf{3}$ & $\mathbf{4}$ \\
\hline Настоянка горіха волоського спиртова & 5,0 & 5,0 & 10,0 & 10,0 \\
\hline Мірамістин & - & 0,5 & - & 0,5 \\
\hline Лідокаїну гідрохлорид & - & 5,0 & - & 5,0 \\
\hline ДМСО & 3,0 & 3,0 & 3,0 & 3,0 \\
\hline Полісорбат 80 & - & 3,0 & - & 3,0 \\
\hline ПЕО 1500 & 20,0 & 20,0 & 23,0 & 20,0 \\
\hline ПЕО 400 & 72,0 & 63,5 & 64,0 & 58,5 \\
\hline
\end{tabular}

Виготовлені зразки комбінованої мазі на основі спиртової настоянки горіха волоського відповідають вимогам ДФУ 2. Зразки якісного і кількісного складу експериментальних композицій з екстрактом горіха волоського вуглекислотного різного вмісту у комбінації з мірамістином і лідокаїну гідрохлоридом наведені у таблиці 5.

Таблиця 5

\section{Склад експериментальних композицій} з екстрактом горіха волоського вуглекислотного

\begin{tabular}{|l|c|c|c|c|c|}
\hline \multirow{2}{*}{ Найменування інгредіснту } & \multicolumn{5}{|c|}{ № складу на 100 г, г } \\
\cline { 2 - 7 } & $\mathbf{1}$ & $\mathbf{2}$ & $\mathbf{3}$ & $\mathbf{4}$ & $\mathbf{5}$ \\
\hline Екстракт горіха волоського вуглекислотний & 1,0 & 2,0 & 3,0 & 5,0 & 5,0 \\
\hline Мірамістин & - & 0,5 & 0,5 & - & 0,5 \\
\hline Лідокаїну гідрохлорид & - & 5,0 & 5,0 & 5,0 & 5,0 \\
\hline ДМСО & 3,0 & 3,0 & 3,0 & 3,0 & 3,0 \\
\hline Полісорбат 80 & 3,0 & 3,0 & 3,0 & 3,0 & 3,0 \\
\hline ПЕО 1500 & 22,0 & 20,0 & 20,0 & 20,0 & 20,0 \\
\hline ПЕО 400 & 71,0 & 66,5 & 65,5 & 64,0 & 63,5 \\
\hline
\end{tabular}


Виготовлені зразки комбінованої мазі на основі екстракту горіха волоського відповідають вимогам ДФУ 2.

3 метою вибору оптимального складу комбінованої мазі на основі екстракту (настоянки) горіха чорного або волоського для лікування ран та ранової інфекції подалі досліджували протимікробну активність розроблених експериментальних композицій на музейних штамах бактерій і грибах роду Candida та вивчали ефективне співвідношення діючих речовин за ранозагоювальною дією на експериментальній моделі ранового процесу.

\section{4. Висновки}

3 метою створення нового комбінованого лікарського засобу протимікробної дії для лікування ранової патології та ії̈ ускладнень щодо вивченна протимікробна активність лікарських форм з горіхами чорним та волоським, їхня протимікробна активність. За цим визначене ефективне співвідношення діючих речовин за ранозагоювальною дією на експериментальній моделі ранового процесу, протимікробну активність (показники МІК, МБцК і МФК), розроблених композицій, оптимальний склад відносно поширеного спектру штамів мікроорганізмів, що притаманні рановому процесу, його протизапальній, ранозагоювальній дії. Спиртові настоянки/екстракти горіхів чорного і волоського, композицій у формі мазі з різною концентрацією вищезазначених речовин відповідають стандартним вимогам ДФУ та у концентраціях 5\% спиртової настоянки горіха чорного $10 \%$ спиртової настоянки горіха волоського, екстрактом горіха волоського вуглекислотного у концентрації 3\% проявляють найбільш високу активність до збудників ранової інфекції.

\section{References:}

1. Cheraief I., Boussaada O., Gannoun S. (2018). Chemical composition and antimicrobial activity of walnut oil. Journal of Essential Oil Research, 21, 180-84.

2. Cooper R. (2014). Honey as an effective antimicrobial treatment for chronic wounds: Is there a place for it in modern medicine? Chronic Wound Care Manag, $1,15-22$.

3. Cutting K., White R. (2005). Criteria for identifying wound infection revisited. Ostomy Wound Manag, 51, 28-34.

4. Fatemeh Cheraghali1, Saeedeh Shojaee-aliabadi1, Seyede Marzieh (2018). Hosseini Characterization of microcapsule containing walnut (Juglans regia L.) 
green husk extract as preventive antioxidant and antimicrobial agent. International Journal of Preventive Medicine, 9(1), 101.

5. Khanh-V., Zhentian L., Lloyd W., Mark V. (2018). Identifying Antibacterial Compounds in Black Walnuts (Juglans nigra) Using a Metabolomics Approach. Metabolites, 8(4), 58.

6. Khanh-Van, Danh C. (2019). Production From LipopolysaccharideStimulated Human Promonocytic Cell Line U-937. URL: https://doi.org/10.3389/ fphar.2019.01059

7. Kocacaliskan I., Albayrakb A., Ilhan S. (2018). Varietal Differences in Antimicrobial Activities of Walnut (Juglans regia L.) Leaf Extracts. Gaziosmanpasa Journal of Scientific Research, 7(3), 173-180.

8. Lu J., Yang M., Zhan M., Xu X., Yue J., Xu T. (2016). Antibiotics for treating infected burn wounds. Cochrane Database Syst. Rev. 2.CD012084.

9. Negut I., Grumezescu V., Mihai A. Grumezescu (2018). Treatment Strategies for Infected Wounds. Molecule, 23(9). 2392.

10. Petre A. (2019). Black Walnuts: A Nutritious Nut Reviewed. URL: https://www.healthline.com/nutrition/black-walnut\#what-they-are

11. Randolph K., Rose A., Oswalt C., Brown M. (2013). Status of black walnut (Juglans nigra L.) in the eastern United States in light of the discovery of thousand cankers disease. Castanea, 78(1), 2-14.

12. Ramasubbu D.A., Smith V., Hayden F., Cronin P. (2017). Systemic antibiotics for treating malignant wounds. Cochrane Database Syst. Rev., 8. CD011609.

13. Ros, E. (2015). Nuts and CVD. Br. J. Nutr. 113(S2), 111-120.

14. Saddiqe Z., Naeem I., Maimoona A. (2010). A review of the antibacterial activity of Hypericum perforatum L. J. Ethnopharmacol. 131, 511-521.

15. Willis L., Bielinski D., Fisher D., Matthan N. (2010). Walnut extract inhibits LPS-induced activation of BV-2 microglia via internalization of TLR4: possible involvement of phospholipase D2. Inflammation, 33(5), 325-333.

16. Vu D., Vo P., Coggeshall M. Lin C. (2018). Identification and characterization of phenolic compounds in black walnut kernels. J. Agric. Food Chem, 66(17), 4503-4511.

17. Zenati F., Benbelaid F., Khadir A., Bellahsene C., Bendahou M. (2014). Antimicrobial effects of three essential oils on multidrug resistant bacteria responsible for urinary infections. J. Appl. Pharm, 4, 15-18. 